\title{
Penyuluhan Penerapan Protokol Kesehatan Pada Masa Pandemi COVID-19 Di Kelurahan Manggala
}

\author{
Herlinda Mahdania Harun*, Rusli, Salsabila Dwi Yunita \\ Radiologi, Politeknik Kesehatan Muhammadiyah Makassar \\ *E-mail: herlinda@poltekkesmu.ac.id
}

\begin{abstract}
COVID-19 is a group of infectious disease caused by the corona virus (SARS-CoV-2). The spread of this virus so quickly to various countries in the world, including Indonesia, has resulted in COVID-19 becoming a global pandemic as a result of which efforts to prevent and control this disease are expected. Residents have an important role in breaking the chain of transmission of COVID-19 so as not to cause new infections. Given the mode of transmission from individual to individual, transmission can occur both at home, traveling, at work, places of worship, tourist areas as well as other areas where people interact socially. Therefore, this service aims to provide knowledge to the community in the form of counseling so as to apply health protocols during the COVID-19 pandemic. Counseling uses lecture, discussion, and question and answer methods. The results of the counseling activity that was held for a day showed that there was still a lack of awareness of the residents of the Manggala village regarding efforts to implement health protocols during the COVID-19 pandemic. The counseling was attended by stakeholders and received a good response, this can be seen from the questions from the local community.
\end{abstract}

Keywords : Counseling, Health Protocol, COVID-19

\begin{abstract}
Abstrak
COVID-19 ialah kelompok penyakit menular yang ditimbulkan virus corona (SARS-CoV-2). Penyebaran virus ini begitu cepat ke banyak sekali negara di dunia, termasuk Indonesia mengakibatkan COVID-19 menjadi pandemik global sebagai akibatnya diharapkan upaya pencegahan dan pengendalian penyakit ini. Warga memiliki peran penting d memutus mata rantai penularan COVID-19 agar tidak mengakibatkan penularan baru. Mengingat cara penularannya dari individu ke individu, maka penularan bisa terjadi baik di rumah, berpergian, tempat kerja, tempat ibadah, daerah wisata juga daerah lain dimana ada orang berinteraksi sosial. Oleh karena itu, pengabdian ini bertujuan agar memberikan pengetahuan pada masyarakat berupa penyuluhan sehingga menerapkan protokol kesehatan pada masa pandemi COVID-19. Penyuluhan memakai metode ceramah, diskusi, serta tanya jawab. Hasil kegiatan penyuluhan yang diselenggarakan selama sehari diperoleh bahwa masih kurangnya kesadaran warga kelurahan Manggala terkait upaya penerapan protokol kesehatan di masa pandemik COVID-19. Penyuluhan dihadiri oleh para stakeholder dan menerima sambutan baik hal ini dapat dilhat dari pertanyaan-pertanyaan oleh masyarakat setempat.
\end{abstract}

Kata kunci : Penyuluhan, Protokol Kesehatan, COVID-19

\section{PENDAhUluAN}

Problem kesehatan pada seluruh dunia saat ini akibat virus Corona. Virus yang timbul di Wuhan, Cina dan menyebar ke semua dunia termasuk Indonesia (Kemenkes RI, 2020). Usaha pengendalian terhadap jenis penyakit menular tersebut harus dilakukan setepat mungkin. Protokol kesehatan telah ditetapkan WHO dan Kementerian Kesehatan RI akan berguna apabila masyarakat dibekali dengan pengetahuan, sikap dan keterampilan. Tindakan tersebut yakni menggunakan masker, social distancing, jaga jarak minimal 2 meter, sering cuci tangan menggunakan sabun air mengalir atau membawa antiseptik, memakai alat makan sendiri, serta upaya lainnya (Liu F, et al., 2020);(Athena A., 2020). Dilihat asal cara penularannya, transmisi terjadi melalui percikan-percikan (droplet) melalui hidung atau mulut orang yang terjangkit COVID-19 ketika bernafas atau batuk (Kemenkes RI, 2020). 
Pandemi ini membuat semua orang wajib mengikuti keadaan menggunakan pola hidup pada masa pandemi. Salah satunya yakni kebiasaan baru terkait disiplin protokol kesehatan supaya dapat mengurangi penularan wabah virus corona. Hanya saja, pada penerapannya banyak dari mereka tidak mematuhi protokol kesehatan yang dikeluarkan pemerintah. Hal tersebut dikhawatirkan dapat menambah kasus penyebaran penyakit. Tingginya angka penularan kasus virus corona di Indonesia masih disebabkan karena kurangnya kepedulian terhadap ancaman oleh virus ini seperti orang yang tidak pakai masker luar rumah. Tiap orang memiliki potensi untuk terinfeksi virus corona tetapi pada beberapa kelompok memiliki taraf risiko lebih tinggi buat terkena virus corona hingga kematian.

Menanggapi hal ini, masyarakat Indonesia perlu mempunyai kesadaran dan kebiasaan hidup bersih pada masa pandemi. Upaya pencegahan serta mitigasi merupakan kunci penerapan pelayanan kesehatan masyarakat. Penularan pada fasilitas umum disebabkan adanya mobilisasi, kerumunan atau interaksi orang. Pengetahuan juga sikap masyarakat terhadap penerapan protokol kesehatan diharapkan bisa menurunkan jumlah kasus covid agar pandemi ini bisa dengan cepat berakhir. Usaha yang dilakukan agar kesadaran masyarakat meningkat yaitu perlu dilakukan penyuluhan tentang penerapan protokol kesehatan di semua lapisan warga. Olehnya, pengabdian masyarakat ini dilakukan tujuannya untuk memberikan pengetahuan pada masyarakat melalui penyuluhan penerapan protokol kesehatan masa pandemi covid.

\section{METODE}

Metode yang diterapkan pada kegiatan pengabdian kepada masyarakat (PKM) ini berupa pemberian penyuluhan kesehatan kepada masyarakat Kelurahan Manggala, Kec. Manggala Kota Makassar. Kegiatan pengabdian ini dilaksanakan dengan memerhatikan protokol kesehatan yang ditetapkan oleh pemerintah sesuai Keputusan Menteri Kesehatan RI No. HK. 01.07/MENKES/382/2020 perihal protokol kesehatan bagi warga pada kawasan dan fasilitas umum untuk pencegahan dan pengendalian COVID (Kemenkes RI, 2020). Kegiatan pengabdian ini dilakukan bersama dengan prodi teknik laboratorium medis dan sanitasi yang mana mereka melakukan praktek kerja nyata (PKN) diantaranya penyuluhan dan pemberian tempat sampah kepada warga setempat. Kemudian prodi radiologi memberikan penyuluhan kedua terkait protokol kesehatan di masa pandemi COVID-19.

Media yang digunakan pada kegiatan PKM ini adalah pemaparan materi dari narasumber selaku dosen Prodi D3 Radiologi Poltekkesmuh Makassar berupa slide presentasi menggunakan LCD dan sosialisasi langsung oleh mahasiswa prodi D3 Radiologi Politeknik Kesehatan Muhammadiyah Makassar yakni cara menggunakan masker dan mencuci tangan yang benar. Kegiatan ini dilaksanakan di Mesjid Al Jihad H. Abdul Razak Dg. Tutu Manggala dengan mengatur posisi duduk warga yang hadir yaitu 1 meter. Penyuluhan dihadiri oleh ketua RT 009/ RW 009, dan 21 orang warga Kelurahan Manggala. Materi penyuluhan disampaikan dengan metode ceramah, diskusi dan tanya jawab. Seluruh peserta dapat mengajukan berbagai pertanyaan terkait materi penyuluhan. Kemudian di tutup dengan pembagian berupa masker dan hand sanitizer.

\section{HASIL DAN PEMBAHASAN}

Kegiatan pengabdian ini berupa penyuluhan kesehatan kepada warga, Kelurahan Manggala, Kecamatan Manggala Kota Makassar. Penyuluhan kesehatan yang telah diberikan yaitu pentingnya penerapan protokol kesehatan pada masa pandemi COVID-19. Hal ini didasarkan sebab mudahnya virus COVID-19 ini menular ke manusia dalam waktu yang begitu cepat sehingga dibutuhkan pencegahan dan pengendalian penyakitnya. Sumber penularan penyakit ini diantaranya dari droplet ketika seseorang batuk/ bersin, memegang permukaan yang terkontaminasi virus corona yang menyebar melalui udara terutama di ruangan tertutup ataupun ventilasi jendela yang buruk.

Secara umum penerapan protokol kesehatan diperlukan di masa pandemi seperti menggunakan masker, menjaga jarak dari orang lain, mencuci tangan dengan sabun dan air mengalir atau memakai handsanitizer serta menghindari kerumunan baik di dalam maupun di luar rumah bersama orang lain (Novalia \& Handayani Lina, 2021). Pada saat penyuluhan ini masyarakat antusias bertanya dan mendengarkan dengan baik penyuluhan yang diberikan. Penyuluhan ini dilaksanakan di mesjid yang dihadiri oleh ketua RT, warga kelurahan Manggala khususnya RT 009/ RW 009. Dari 21 orang warga 
Kelurahan Manggala sebagian besar dihadiri oleh ibu-ibu. Diharapkan dapat mengingatkan diri dan keluarganya agar selalu menerapkan protokol kesehatan dimanapun berada.

Adapun cara buat menggunakan masker wajib sesuai menggunakan standar kesehatan, mengganti masker tiap $4 \mathrm{jam} /$ sebelum 4 jam dan bila telah lembab atau basah. Buat masker medis digunakan hanya satu kali pakai digunting atau dibuang. Buat masker kain di cuci memakai detergen. Apabila ada anggota keluarga atau warga sekitar yang tertuar Covid tindakan yang dilakukan yaitu tidak panik jika ada warga yang terkena karena dapat mengurangi sistem kekebalan tubuh, membatasi diri buat berinteraksi secara fisik dengan warga sekitar, tidak menyampaikan stigma negatif dan menumbuhkan rasa empati baik kepada yang terpapar maupun yang telah sembuh dari Covid, tetap menerapkan 3M (cuci tangan pakai air mengalir dan sabun, jaga jarak minimal 1 meter untuk menghindari percikan droplet ketika orang batuk atau bersin. Ingatkan masyarakat jaga kebersihan dan disinfeksi lingkungan tempat tinggal masing-masing. Menaikkan imunitas tubuh dengan menerapkan pola hidup bersih dan sehat (PHBS) antara lain konsumsi gizi seimbang, Mengelola penyakit penyerta/komorbid supaya tetap terkontrol (Utami, Mose, Martini, 2020).

Melaporkan pada satgas yang menangani Covid baik RT/RW setempat jika ada warga positif menderita dan melanggar protokol kesehatan ketika keluar rumah. Adapun disampaikan juga protokol kesehatan bagi pasien di instalasi radiologi yaitu secara umum tetap menggunakan masker ketika memasuki Rumah Sakit, menyiapkan handsanitezer sendiri, tidak menyentuh muka terutama bagian mulut, hidung, serta mata, jaga jarak dengan pasien lain $>1$ meter. Laporkan kondisi atau gejala sakit yang diderita sejujurnya pada petugas.

Sejalan dengan pengabdian (Faizah, Restu \& Mandiyo Priyo, 2020) yang dilakukan pada anggota PKK bahwa sesudah aktivitas dilaksanakan, peserta menerima pengetahuan cara memakai masker, cuci tangan yang benar dan tepat, juga etika batuk. Tidak hanya edukasi yang diberikan, peserta juga menerima masker, hand sanitizer, dan hand wash. Edukasi penerapan protokol kesehatan juga diberikan oleh (Irmayani, Bangun, Parinduri, \& Octavariny, 2021) bahwa sebelum penyuluhan mayoritas masyarakat mencuci tangan pakai sabun saat berkegiatan, sebagian besar tidak membawa handsanitizer ketika berpergian, seluruhnya menggunakan masker saat keluar, ketika berinteraksi tidak jaga jarak, serta mayoritas tidak berolahraga dan tidak mengkonsumsi gizi seimbang.

Hasil dari penyuluhan (Farokhah, Ubaidillah, Yulianti, 2020) diperoleh yakni wawasan serta pengetahuan warga setempat tinggi akan disiplin protokol kesehatan, warga mempunyai masker kain sebagai pelindung dirinya, dan juga warga memiliki kesadaran tinggi akan bahaya virus covid. Kemudian dilakukan evaluasi terhadap pengetahuan dan kepatuhan penerapan protokol kesehatan peserta meningkat setelah diberikan informasi tentang COVID-19 (Lidya, et al., 2021).

Penyuluhan ini diselenggarakan dengan tujuan untuk memberikan pengetahuan kepada masyarakat Kelurahan Manggala Kecamatan Manggala Kota Makassar dan menentukan tindakan yang akan dilakukan terkait dengan diri mereka yakni mencegah dan mengendalikan penularan virus corona. Seluruh peserta dapat mengajukan berbagai pertanyaan terkait materi penyuluhan yang diberikan. Pada tahap kedua pemberian tempat sampah organik dan non organik oleh mahasiswa PKN Politeknik KesehatanMuhammadiyah Makassar. Pada saat pelaksanaan kegiatan terlihatantusiasme warga dengan berbagai pertanyaan yang dilontarkan oleh peserta. Diharapkan warga beserta para stakeholder dapat mengimplementasikan secara langsung hasil penyuluhan.

Kegiatan penyuluhan yang diselenggarakan selama sehari, mendapat sambutan yang baik dari stakeholder dan warga yang menghadiri penyuluhan. Keadaan ini dapat dilihat dari kehadiran peserta yang cukup memenuhi Mesjid Al Jihad. Didukung juga mahasiswa Politeknik Kesehatan Muhammadiyah Makassar yang sedang PKN di kelurahan tersebut. 


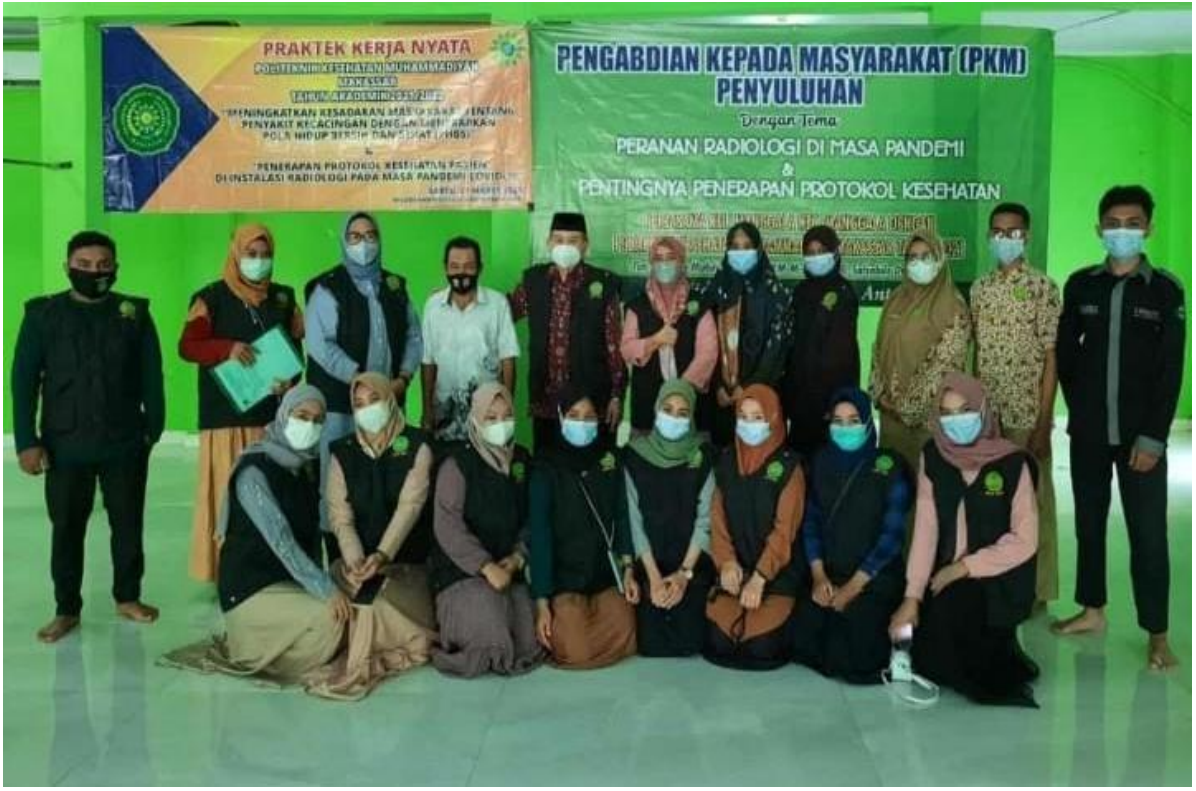

Gambar 1. Foto bersama Direktur Poltekkesmuh Makassar, Ketua RT, Dosen dan Mahasiswa Poltekkesmuh Makassar

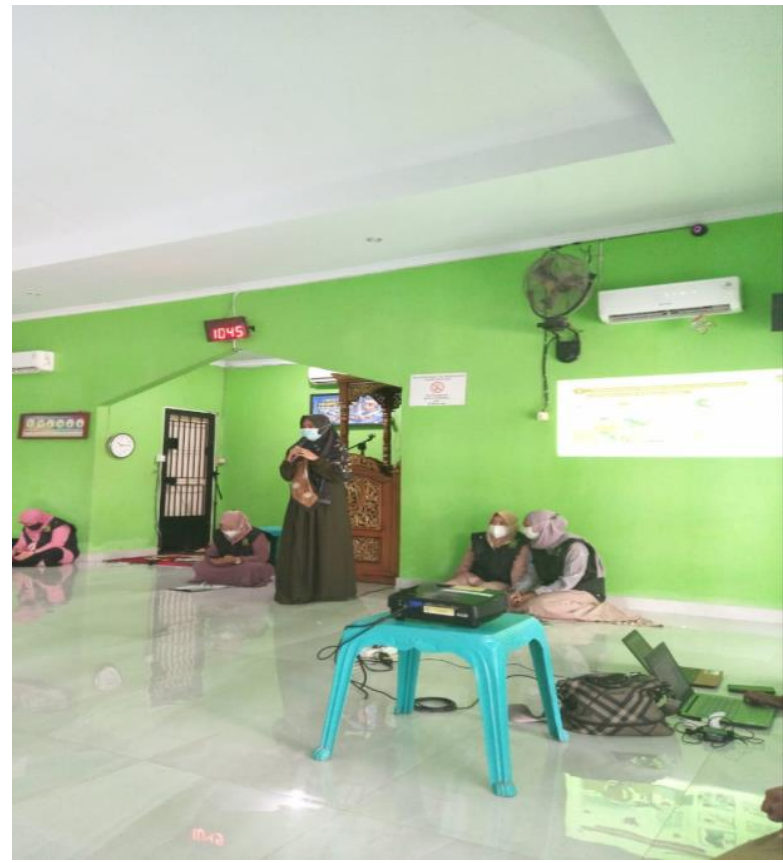

(a)

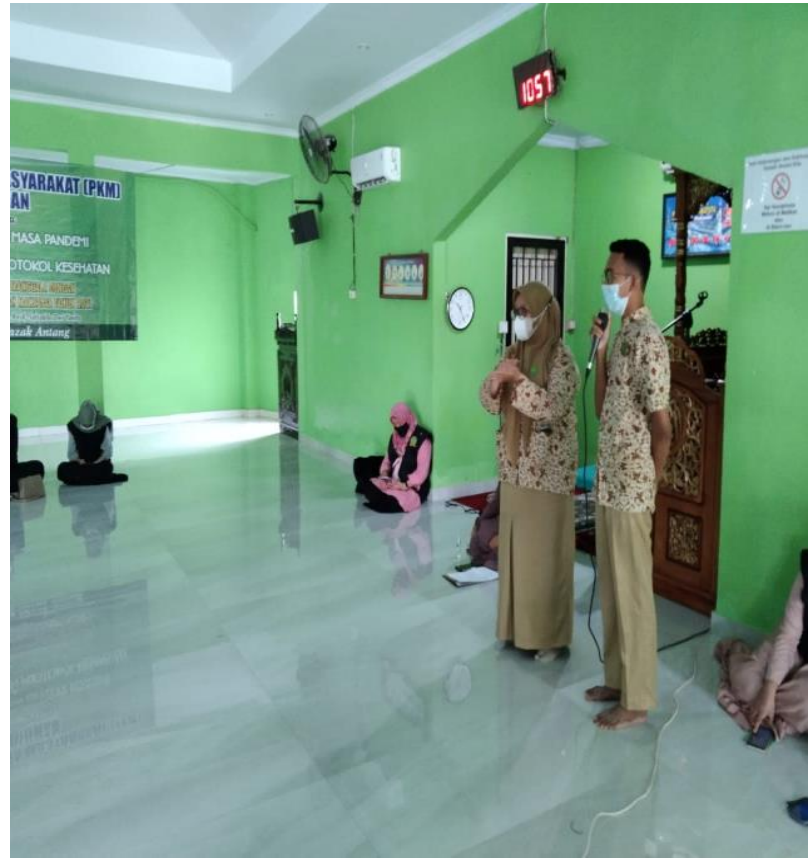

(b)

Gambar 2 . (a) Penyuluhan Penerapan Protokol Kesehatan COVID-19 kepada warga (b) Penyuluhan tentang cara memakai masker dan mencuci tangan oleh mahasiswa D3 Radiologi Poltekkesmuh Makassar

\section{KESIMPULAN}

Warga Kelurahan Manggala beserta para stakeholder setempat masih kurang pengetahuan akan isu kesehatan terkait penerapan kesehatan pada masa pandemi covid. Dari penyuluhan ini diperlukan agar warga sadar dalam menerapkan protokol kesehatan. Kemudian kegiatan penyuluhan disusun untuk bahan pijakan dalam melaksanakan kegiatan pengabdian kepada masyarakat berikutnya. Disadari bahwa pelaksanaan kegiatan banyak kekurangan-kekurangan sehingga jauh dari kesempurnaan. Diharapkan 
masyarakat Kelurahan Manggala dapat meakukan upaya dalam mencegah/ mengendalikan penyebaran virus SARS-CoV-2 di lingkungan setempat.

\section{UCAPAN TERIMA KASIH}

Penulis mengucapkan terima kasih kepada pihak institusi Poltekkes Muhammadiyah Makassar yang telah memberikan kesempatan kepada kami untuk dapat melaksanakan penyuluhan ini dan membantu segala proses kegiatan dapat berlangsung baik. Terima kasih juga kepada para stakeholder dan masyarakat Kelurahan Manggala atas waktunya dan telah menerima kami dengan baik sehingga kegiatan pengabdian ini dapat berjalan dengan baik dan lancar.

\section{DAFTAR PUSTAKA}

Athena, A., Laelasari, E., Puspita, T. (2020). Pelaksanaan Disinfeksi Dalam Pencegahan Penularan Covid-19 Dan Potensi Risiko Terhadap Kesehatan Di Indonesia. J Ekol Kesehat, 19(1):1-20. doi:10.22435/jek.v19i1.3146

Faizah, Restu \& Mandiyo Priyo. (2020). Penerapan Protokol Kesehatan Di Masa Pandemi Covid-19 pada anggota PKK RT.05 Desa Banyuraden. Prosiding Semnas PPM 2020: 282-288.

Farokhah, L., Ubaidillah, Y., Yulianti, R.A. (2020). Penyuluhan Disiplin Protokol Kesehatan Covid-19 Di Kelurahan Gandul Kecamatan Cinere Kota Depok. Jurnal UMJ; 2714-6286.

Irmayani, Bangun, Sri M.Br., Parinduri, A.I., Octavariny, R. (2021). Edukasi Tentang Penerapan Protokol Kesehatan Dalam Upaya Pencegahan Covid-19. Jurnal Pengmas Kestra,Vol. 1 No.1 Edisi Juni 2021.

Kemenkes, RI. (2020). Pedoman Pencegahan dan Pengendalian Coronavirus Disease (COVID-19). Germas.

Kemenkes, RI. (2020). Protokol Kesehatan Bagi Masyarakat di Tempat dan Fasilitas Umum dalam Rangka Pencegahan dan Pengendalian Corona Virus Disease 2019 (covid-19), HK.01.07/Menkes/382/2020 Keputusan Menteri Kesehatan Republik Indonesia Nomor (2020).

Lidya, V., Pasaribu, D., Dwiyatni, A., Sabina, C., Ridwan, M., Gunawan, DD., et al. (2021). Evaluasi Penerapan 3M Dimasa Pandemic COVID-19. 2021;2(2):54- 60.

Liu, F., Wang, W., Yu, H., et al. (2020). Prevention and control strategies of general surgeons under COVID-19 pandemic. Surg Pract Sci, 1(April):100008. doi:10.1016/j.sipas.2020.100008

Novalia, Dewi Prima \& Handayani Lina. (2021). Penerapan Protokol Kesehatan 3M Di Masyarakat Pada Masa Pandemi Covid-19 : Literature Review. Visikes 20(02): 318-325, 2021; http://dx.doi.org/10.33633/visikes.v20i2.4653

Utami, R.A., Mose, R.E., Martini, M. (2020). Pengetahuan, Sikap dan Keterampilan Masyarakat dalam Pencegahan COVID-19 di DKI Jakarta. J Kesehat Holist,4(2):68-77. 